Emergence and Embodiment 
SCIENCE AND CULTURAL THEORY

A Series Edited by Barbara Herrnstein Smith and E. Roy Weintraub 


\section{Emergence and Embodiment}

New Essays on Second-Order Systems Theory

EDITED BY BRUCE CLARKE AND MARK B. N. HANSEN

Duke University Press • Durham \& London • 2009 
(C) 2009 Duke University Press All rights reserved Printed in the United States of America on acid-free paper $\infty$ Designed by Amy Ruth Buchanan Typeset in Minion by Achorn International Inc. Library of Congress Cataloging-inPublication Data appear on the last printed page of this book. 